\title{
Effect of humic acid on growth and productivity of okra (Abelmoschus esculentus) cultivars
}

Nadeem Haider ${ }^{*}$, Mehboob Alam ${ }^{1}$, Haji Muhammad ${ }^{2}$, Islam Gul ${ }^{3}$, Saeed U1 Haq ${ }^{4}$, Sadiq Hussain ${ }^{5}$ and Abdul Rab

1. Department of Horticulture, The University of Agriculture, Peshawar-Pakistan

2. Agriculture Extension Department Mardan, Khyber Pakhtunkhwa-Pakistan

3. Department of Agriculture Economics, The University of Agriculture, Peshawar-Pakistan

4. College of Horticulture, North West A\&F University, Yangling, Shaanxi-China

5. Department of Soil and Environmental Sciences, The University of Agriculture, Peshawar-Pakistan

6. Department of Agronomy, The University of Agriculture, Peshawar-Pakistan

*Corresponding author's email: nadeemjan529@aup.edu.pk

Citation

Nadeem Haider, Mehboob Alam, Haji Muhammad, Islam Gul, Saeed U1 Haq, Sadiq Hussain and Abdul Rab. Effect of humic acid on growth and productivity of okra (Abelmoschus esculentus) cultivars. Pure and Applied Biology. Vol. 6, Issue 3, pp932-941. http://dx.doi.org/10.19045/bspab.2017.60098

\begin{tabular}{llll}
\hline \hline Received: 19/03/2017 & Revised: 17/07/2017 & Accepted: 21/07/2017 & Online First: 24/07/2017 \\
\hline
\end{tabular}

\section{Abstract}

An experiment to study the effect of humic acid (0, 10, 20, 30 and $\left.40 \mathrm{~kg} \mathrm{ha}^{-1}\right)$ on okra cultivars (Sabz Pari, Green Star, Arka Anamika and Pusa Sawani) was carried out at Dargai, District Malakand during 2015 in randomized complete block design with three replications. It was observed that maximum emergence percentage $(74.53)$, single pod weight $(14.27 \mathrm{~g})$, stem diameter $(19.01 \mathrm{~mm})$, plant height $(129.17 \mathrm{~cm})$, number of branches plant ${ }^{-1}(5.34)$ and maximum yield (12.85 tonnes ha $^{-1}$ ) was produced by cv. Arka Anamika. Non-significant effect of humic acid was noticed on emergence percentage and number of branches plant ${ }^{-1}$ while significantly maximum pod weight $(13.79 \mathrm{~g})$, stem diameter $(19.29 \mathrm{~mm})$, plant height $(129.39 \mathrm{~cm})$ and yield (12.63 tonnes $\mathrm{ha}^{-1}$ ) was recorded when humic acid was applied @ $20 \mathrm{~kg} \mathrm{ha}^{-1}$. On the basis of current study it is concluded that cultivar Arka Anamika performed will under the agro climatic conditions of Dargai as compared to other tested cultivars therefore better growth and higher yield humic acid should be amended @ $20 \mathrm{~kg} \mathrm{ha}^{-1}$ under the agro climatic conditions of Dargai, District Malakand, Khyber Pakhtunkhwa-Pakistan.

Keywords: Humic acid; Okra cultivars; Growth; Production

\section{Introduction}

Okra (Abelmoschus esculentus L.) of the family Malvaceae is an important summer vegetable and cultivated mostly in tropical and subtropical regions throughout the world. Despite the green immature pod which is cooked and used as vegetable, its roots and stem are used for cleaning cane juice in sugar industries [1]. It is a good source of vitamin $\mathrm{A}, \mathrm{B}$ and $\mathrm{C}$, minerals, proteins and iodine [2]. Annually in Pakistan okra is cultivated from mid-March to midMay on an area of 14,461 hectares with the production of $99,893.74$ metric tonnes [3]. The average yield per unit area of okra is low in Pakistan as compared to other 
countries of the world, it might be due to various factors but the main factors which are responsible for it are low nutrition, environmental factors and genotype of the plant [4]. Diverse genotypes respond different to environmental conditions which result variation in their growth, yield and quality [5]. For better plant growth and higher yield it is essential to cultivate high yielding varieties with improved cultural practices and sufficient nutrients supply. Addition of organic matters can improve the soil nutritional status as well as soil texture and its water holding capacity. One of the most effective forms of organic matter is humic acid and it is considered an important component of fertile soils $[6,7]$. It is a well decomposed form of organic matters which influence the physiological processes of plant as well as improve soil physical, chemical and biological properties [1]. Its hormone like activity of cell division and elongation affects the plant growth and development [8, 9]. Humic acid application to soils boost up biological processes in soil and hold the nutrients in easily exchangeable form to minimize their leaching from soil profile with peculating water [10]. It is clarified by many researchers that addition of humic acid increases the uptake of both micro and macro nutrients. Beside the hormonal activities and improving nutritional status, it shows anti-stress affect in plant body when soil $\mathrm{pH}$ and temperature are unfavorable for plant growth [11]. The present study was carried out to examine the role of humic acid in enhancing the nutritional status of the soils and anti-stress role on growth and yield of various okra cultivars.

\section{Materials and methods}

\section{Experimental site and field preparation}

The research was carried out in farmer field at Dargai, District Malakand, Khyber Pakhtunkhwa-Pakistan during 2015. Field layout was designed by using randomized complete block design in split plot arrangement and replicated three times. Each replication was made by five main plots of $5.40 \mathrm{~m} \times 1.50 \mathrm{~m}$ and each main plot consists of 4 subplots of $1.35 \mathrm{~m} \times 1.50 \mathrm{~m}$. Various okra cultivars; Sabz Pari, Arka Anamika, Pusa Sawani and Green Star were sown in main plots while pre-sowing application of humic acid @ 10, 20,30 and $40 \mathrm{~kg} \mathrm{ha}^{-1}$ along with control were carried out in subplots. The application of recommended fertilizer dose of N-P-K (12060-60) was carried out before seed sowing while nitrogen was applied in two split doses, 50\% pre-sowing and 50\% after 30 days of emergence.

Preparation and soil application of humic acid

Humic acid was purchased from local market of Mahan agrochemical company with brand name Land Saver®. In the product formulation the ratio of humic acid was $50 \%$, therefore the quantity of source was used in doubled @ 4.05, 8.10, 12.15 and $16.20 \mathrm{~g} \mathrm{plot}^{-1}$ respectively, to amend the $10,20,30$ and $40 \mathrm{~kg} \mathrm{ha}^{-1}$. In control plots no humic acid was added.

\section{Seed sowing}

Before sowing, seeds soaking was carried out for all four okra cultivars for $24 \mathrm{hrs}$ in distilled water to encourage the germination rate. On each sowing spot, 3 seeds were sown to reduce the chances of plant missing because of germination failure. Once the plants emergence occurred, thinning was carried out where more than one seedlings were emerged to maintain the desired planting density. Throughout the season similar cultural practices including; irrigation, hoeing, earthing, fertilizer application and weeding was practiced uniformly in each plot.

\section{Data collection}

To study the role of humic acid on various growth and yielding attributes of different 
okra cultivars the data was collected on the basis of following parameters.

\section{Emergence percentage}

Emergence Percentage $=\underline{\text { Number of seeds germinated per treatment }} \times 100$

\section{Number of seeds sown per treatment}

\section{Single pod weight (g)}

Ten pods from each treatment in each replication were randomly selected. Their electronic balance and then average for each treatment was carried out.

\section{Stem diameter (mm)}

Randomly selected five plants in each treatment in each replication were examined for stem diameter. Stem diameter was measured in base, middle and tip of the plant through vernier caliper and there average was carried out.

\section{Plant height (cm)}

Height of five randomly selected plants from each treatment under each replication was measured from ground level to the tip of the plant with the help of measuring tape and its average was calculated.

\section{Number of branches plant ${ }^{-1}$}

Five plants in each treatment in all the three replications were selected and their number of branches were counted manually and then average for each treatment was calculated.

\section{Fresh pod yield (tonnes ha')}

Fresh pod yield of each treatment was recorded in $\mathrm{kg} \mathrm{plot}^{-1}$ and then with the help of the following formula it was converted to tonnes ha- ${ }^{-1}$ :

Total yield $\left(\right.$ tonnes ha $\left.{ }^{-1}\right)=\underline{\text { Yield plot }}{ }^{-1} \times 10,000 \mathrm{~m}^{2}$

\section{Statistical analysis}

$$
\text { Area of the plot }\left(\mathrm{m}^{2}\right)
$$

Statistical analysis was carried out by using MSTATC and MS Excel software's. The means comparisons were carried out at $5 \%$ level of significance [12]. weighing was done with the help of
Emergence percentage of each plot was recorded in all the three replications and average was calculated for each treatment with the help of the following formula.

\section{Results and discussions}

The results of experiment showed significant variation among okra cultivars in terms of emergence percentage, single pod weight, stem diameter, plant height, branches plant ${ }^{-1}$ and fresh pod yield whereas humic acid application significantly improved single pod weight, stem diameter and fresh pod yield.

\section{Emergence percentage}

Figure 1 shows emergence percentage of okra cultivars influenced by humic acid application. The data showed significant role of different genotypes on seed emergence percentage whereas non-significant effect of humic acid on seed emergence percentage was observed. Maximum seed emergence percentage (74.53) was observed in cv. Arka Anamika followed by Pusa Sawani, while minimum emergence percentage (71.41) was showed by cv. Green Star. Each genotype has its own seed source which has a direct effect on various characteristic of seed quality. Similarly seed storage condition and age of seed affects the germination quality of seed which might be the reasons for variation in seed germination percentage of okra cultivars. The results are co-related with the findings of previous study of [4] who reported significant variation in germination percentage of various okra cultivars, similarly the statement of [13] also agreed the results who reported that okra genotypes have nonadditive genes which controlled the germination character of their seeds. 


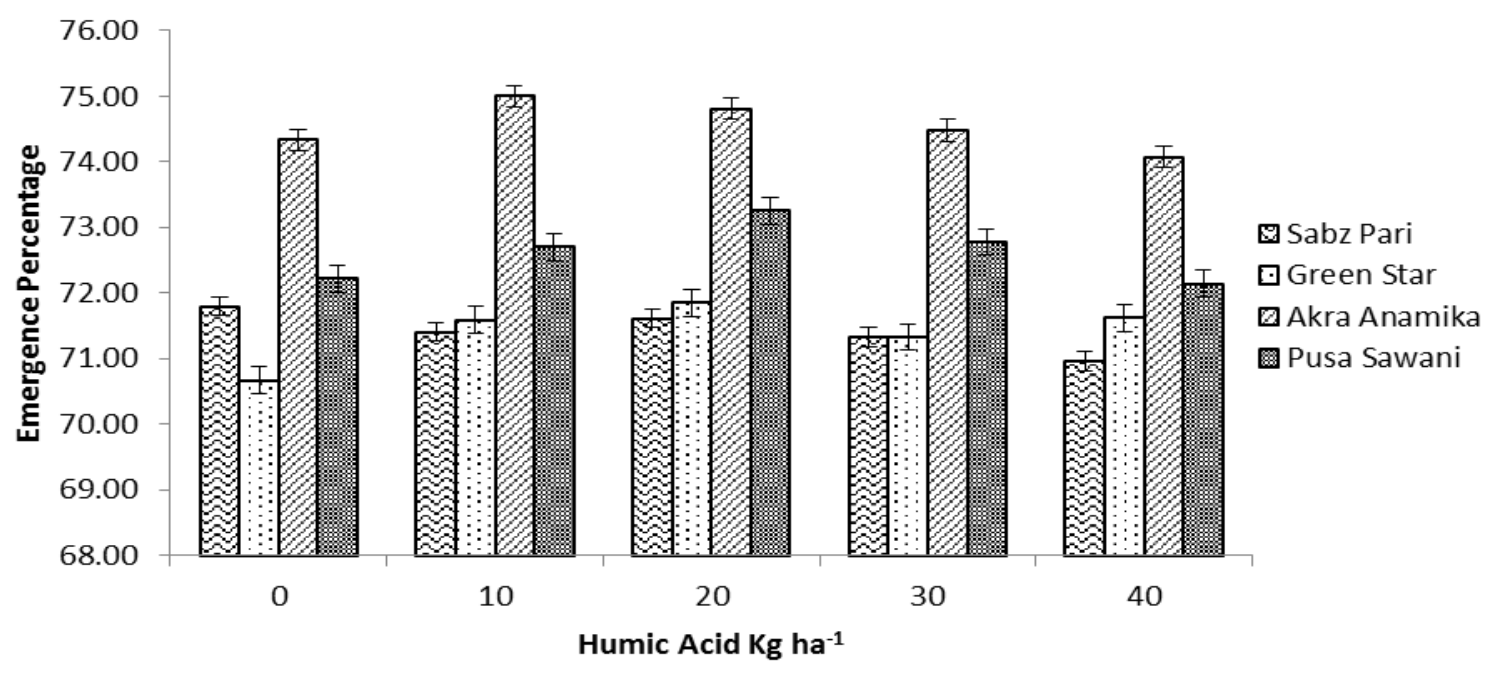

Figure 1. Emergence percentage of different okra cultivars as affected by humic acid levels. Each bar represents average days taken to $50 \%$ emergence of each plot. The error bar on each vertical bar shows standard error

\section{Single pod weight $(\mathrm{g})$}

Data regarding single pod weight influenced by humic acid are presented in Figure 2 . Mean data showed significant role of humic acid and various genotypes on single pod weight of okra. Maximum (14.27 g) single pod weight was recorded in cultivar Arka Anamika while minimum single pod weight $(10.57 \mathrm{~g})$ was observed in cultivar Green Star. The variation might be due to their diverse genetic makeup and high photosynthetic efficiency of some cultivars as compared to other, which affected the single pod weight. The results are supported by various studies of different researchers including; [4, 5, 14, 15] who reported significant difference in the single pod weight of okra cultivars.

As concerned with humic acid, maximum single pod weight (13.79 g) was observed when humic acid was applied @ $20 \mathrm{~kg} \mathrm{ha}^{-1}$ followed by $30 \mathrm{~kg} \mathrm{ha}^{-1}$ while minimum single pod weight $(11.37 \mathrm{~g})$ was noticed in control plots. Humic acid have the abilities of enhancing microbial activities in the soil, boosting up the processes of photosynthesis and respiration and also improve the uptake of various micro and micro nutrients which are the possible reasons of increasing single pod weight of okra. The results of this study are supported by the findings of [16] who found significant increase in the weight of potato with the application of humic acid. Beside this, another researcher [17] reported significant increase in the weight of water melon when humic acid was applied. The study of [18] stated that application of humic acid significantly increase the weight of strawberry fruit. 


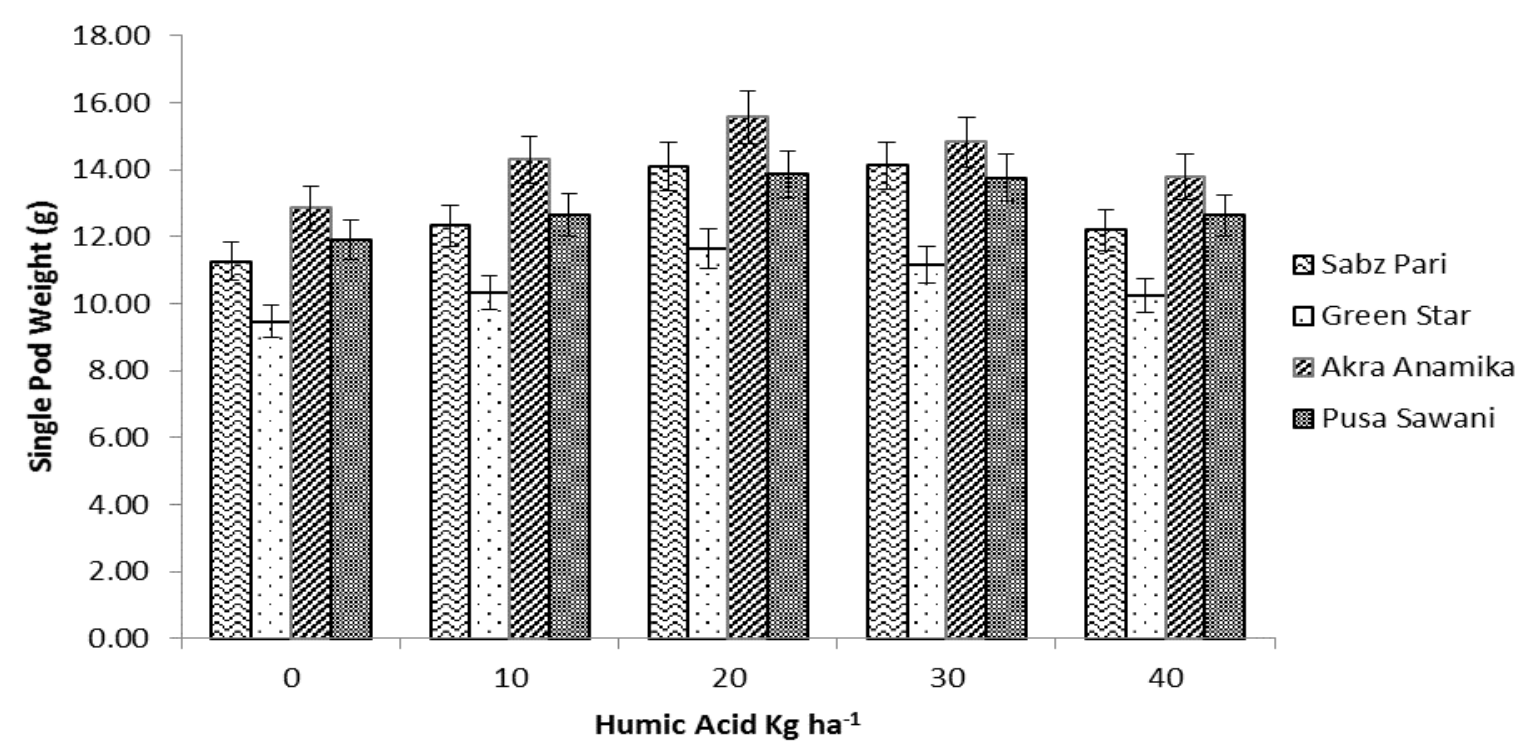

Figure 2. Single pod weight of different okra cultivars as affected by humic acid levels. Each bar represents average pod weight of various okra cultivars in response to different doses of humic acid. The error bar on each vertical bar shows standard error

\section{Stem diameter}

The collected data regarding stem diameter of okra cultivars as influenced by humic acid are presented in Figure 3. Significant variation among okra cultivars as well as application of humic on stem diameter was observed. Maximum stem diameter (19.01 $\mathrm{mm})$ was recorded in cv. Arka Anamika while lowest stem diameter $(17.95 \mathrm{~mm})$ was noticed in cv. Green Star. The variation in stem diameter of okra cultivars might be due to various reasons including plant genetic potential of high rate of photosynthesis, plant tolerance toward various stresses, maximum chlorophyll content and leaf area and maximum plant height which result in capturing maximum sunlight for photosynthesis due to which maximum photosynthate formation occurred and accumulated in stem. The results are supported by the statement of [19] who stated that stem diameter of okra plant is controlled by many genes and it is a main selection parameter for breeding purpose.
Similarly a co-related study of [20] is also in support of the results who reported significant variations in stem diameter of okra cultivars.

Among humic acid levels maximum stem diameter $(19.29 \mathrm{~mm})$ was noticed when humic acid was applied @ 20 kg ha-1 whereas minimum stem diameter (18.07 $\mathrm{mm}$ ) was recorded in control plots. The increase in stem diameter might be due to increase in chlorophyll content, maximum nutrient uptake and increase in photosynthesis and respiration processes because of humic acid, which results in maximum photosynthate accumulation in stem of okra plant [16]. Humic acid have the ability of increasing soil porosity, soil microbial activities and nutrients availability which results in strong vegetative and reproductive growth [21]. The results also supported by the findings of [22] who found significant influence of humic acid on stem diameter of okra plant. 


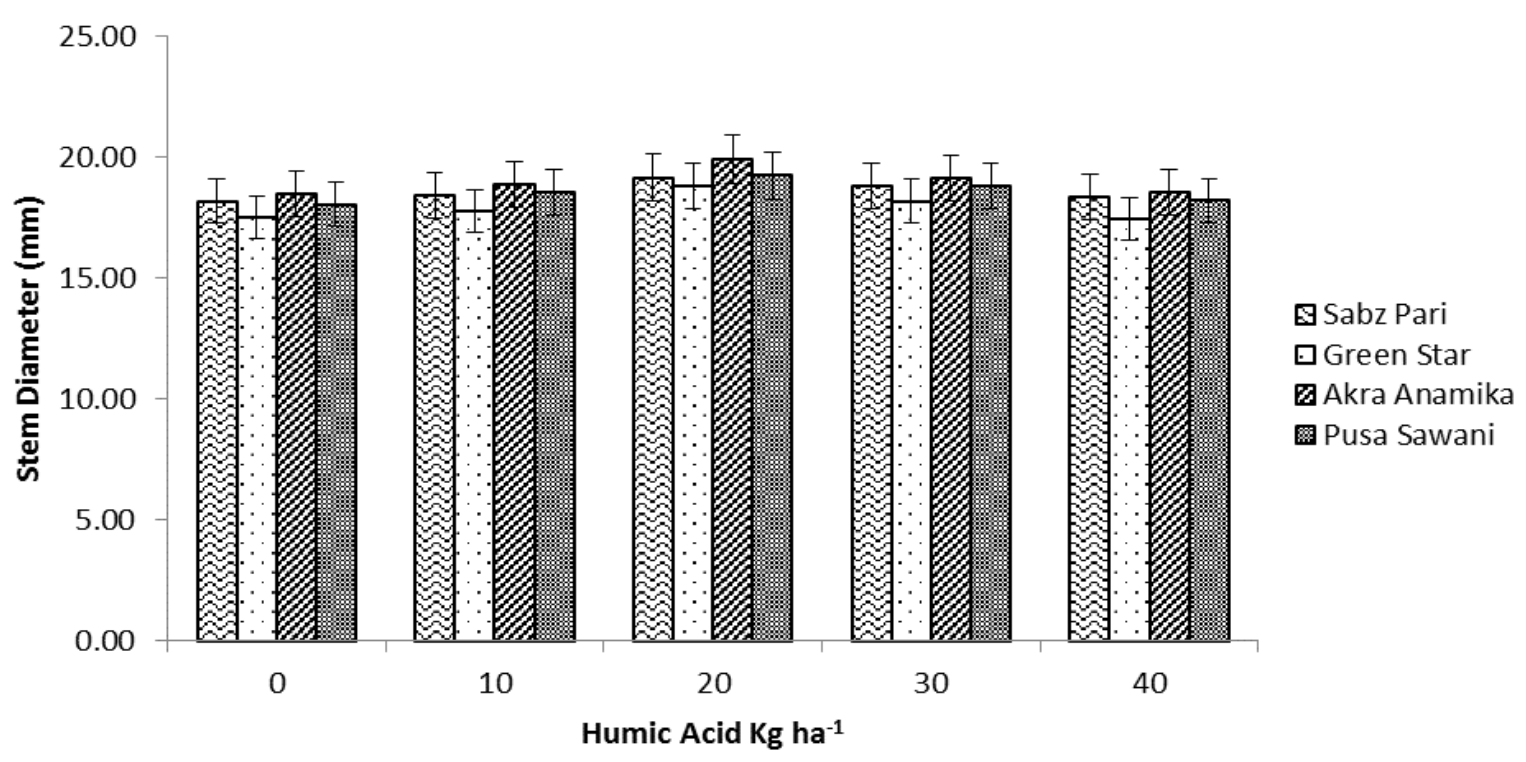

Figure 3. Stem diameter of different okra cultivars as affected by humic acid levels. Each bar represents average stem diameter of different okra cultivars in response to various levels of humic acid. The error bar on each vertical bar shows standard error

\section{Plant height}

Effect of humic acid on plant height of okra cultivars are presented in Figure 4. Significant variation in plant height was noticed among okra cultivars whereas humic acid also showed significant effect on plant height of okra. Maximum plant height $(129.17 \mathrm{~cm})$ was recorded in cv. Arka Anamika followed by Sabz Pari while minimum plant height $(125.24 \mathrm{~cm})$ was noticed in Green Star. The variation in plant height of okra cultivars might be due to genetic makeup as well as more adoptability and inter-specific competitive quality of some cultivars than other. The statement of [23] supported the results who reported that plant height is one of the more variable traits of okra which is very important trait for selection purpose. Similar results are reported by Rahman et al. [24] in plant height of various okra cultivars.

Application of humic acid @ $20 \mathrm{~kg} \mathrm{ha}^{-1}$ showed best results and increased plant height up to $(129.39 \mathrm{~cm})$ which was statistically at par with $30 \mathrm{~kg} \mathrm{ha}^{-1}$ while minimum plant height $(124.33 \mathrm{~cm})$ was recorded in control plots. The variation in plant height might be due to the role of humic acid in nutrient uptake such as nitrogen, sulfur and phosphorous and cell elongation properties [23]. Application of humic acid increases the uptake of calcium which plays a major role in the mitotic cell division of apical meristems and influences the plant height [25]. The similar results are observed by Kirn et al. [2] Gad et al. [26] who reported significant role of humic acid on plant height of okra plant. 


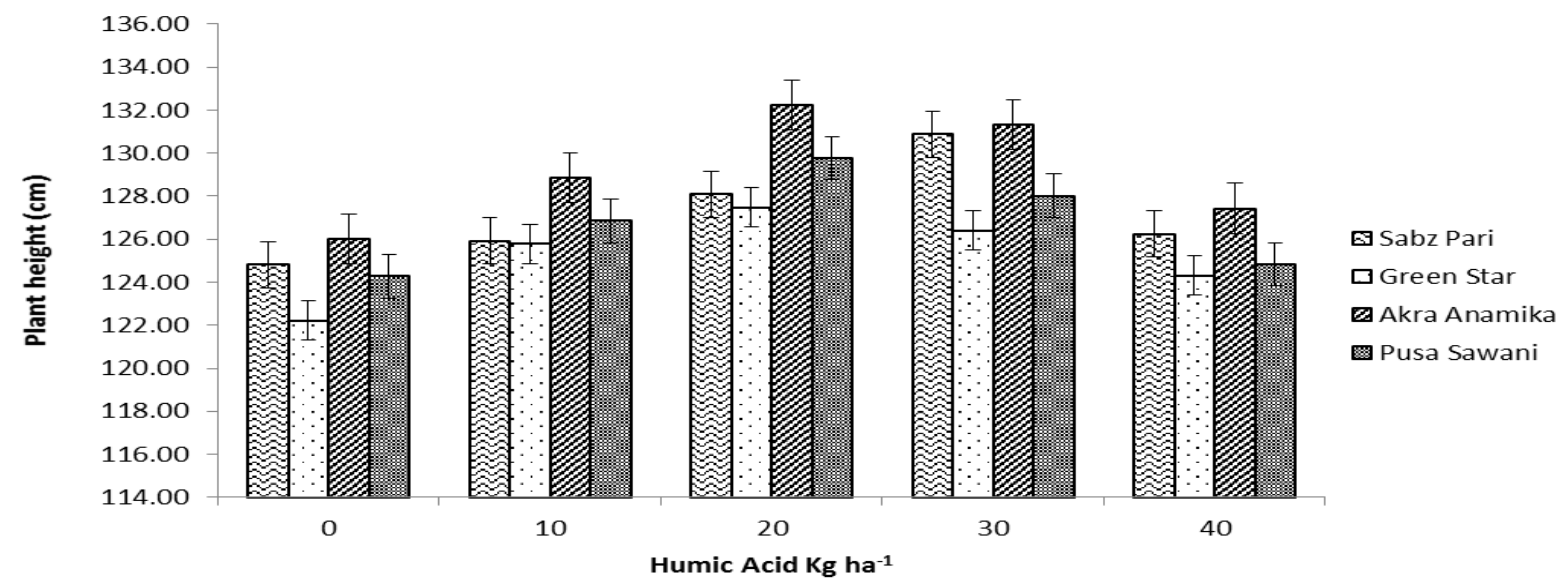

Figure 4. Plant height of different okra cultivars as affected by humic acid levels. Each bar represents the average plant height of different okra cultivars in response to various doses of humic acid. The error bar on each vertical bar shows standard error

Number of branches plant ${ }^{-1}$

The data regarding branches plant $^{-1}$ influenced by humic acid are shown in Figure 5. Non-significant role of humic acid was noticed on number of branches plant $^{-1}$ while significant variation was observed in branches plant $^{-1}$ among okra cultivars. Maximum (5.34) branches plant ${ }^{-1}$ were recorded in cv. Sabz Pari which was statistically at par with cv. Arka Anamika while minimum (4.79) number of branches plant $^{-1}$ were noticed in cv. Green Star. The variation might be due to different genetic characteristics of various genotypes which were fevered by environmental conditions and expressed, because throughout the season same cultural practices were carried out for all cultivars. The results are supported by the findings of [27] who found significant variation in branches plant ${ }^{-1}$ of okra cultivars. Another related study of [23] clarifies the results who reported significant influence of location and season on genetic coefficient of variation of branches plant ${ }^{-1}$ of okra.

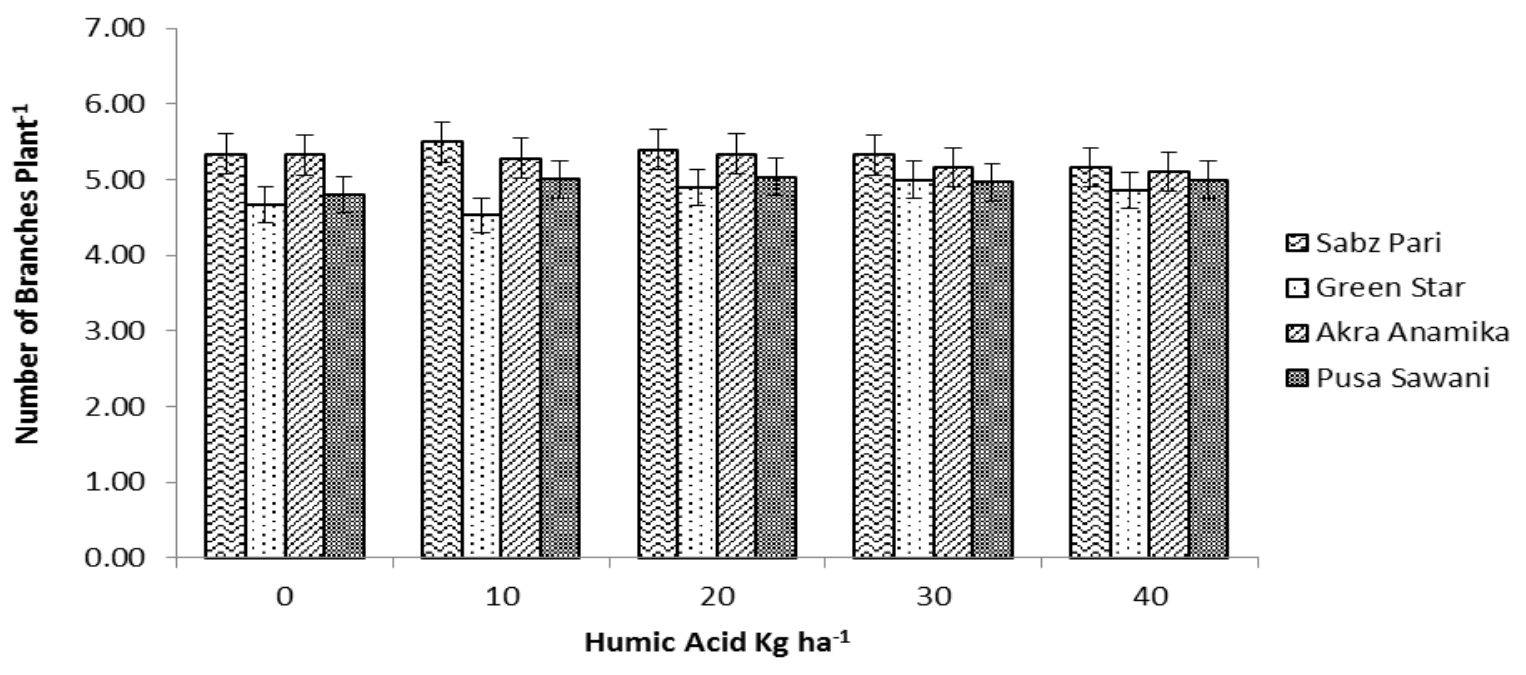

Figure 5. Number of branches plant ${ }^{-1}$ of okra cultivars as affected by humic acid levels. Each bar represents average number of branches plant ${ }^{-1}$ of okra cultivars in response to various levels of humic acid. The error bar on each vertical bar shows standard error 
Fresh pod yield (tonnes ha-1)

Figure 6 shows the role of humic acid on yield of okra cultivars. Significant fluctuation was noticed in the yield of okra cultivars whereas it was also noticed that application of humic acid significantly affected the yield of okra cultivars. Maximum (12.85 tonnes $\left.\mathrm{ha}^{-1}\right)$ fresh pod yield was produced by cv. Arka Anamika while minimum yield $\left(9.78\right.$ tonnes ha $\left.^{-1}\right)$ was recorded in v. Green Star. The variation in fresh pod yield might be due to climatic suitability, more tolerance and high inter specific competitive qualities of some cultivars than other which result in prolong healthy vegetative and reproductive growth. The characteristics of okra including; days to flowering and picking and number of pods plant ${ }^{-1}$ are genetically controlled and favored or suppressed by climatic conditions which have direct effect on fresh pod yield [28]. Similar results were found by many researchers including; $[4,14,24]$ who reported significant fluctuations in fresh pod yield of various okra cultivars.
Application of humic acid @ $20 \mathrm{~kg} \mathrm{ha}^{-1}$ produced significantly maximum (12.63 tonnes $\mathrm{ha}^{-1}$ ) fresh pod yield which was statistically at par with $30 \mathrm{~kg} \mathrm{ha}^{-1}$ whereas minimum yield (10.07 tonnes $\mathrm{ha}^{-1}$ ) was noticed in control plots. The variation in yield might be due to the enormous role of humic acid on nutrients uptake, soil chemical, physical and biological characteristics [21]. Humic acid have the ability to boost up photosynthesis and respiration processes and increase the plant tolerance toward various environmental stresses [11]. Humic acid plays a vast role in stimulation of chlorophyll content of leaf which results in high photosynthetic activity and maximum photosynthate formation and hence directly affected the yield of a crop [29]. The results of this study are in agreement with the findings of [30-32] who found significant increase in the yields of cucumber, pepper and tomato respectively with the application of humic acid.

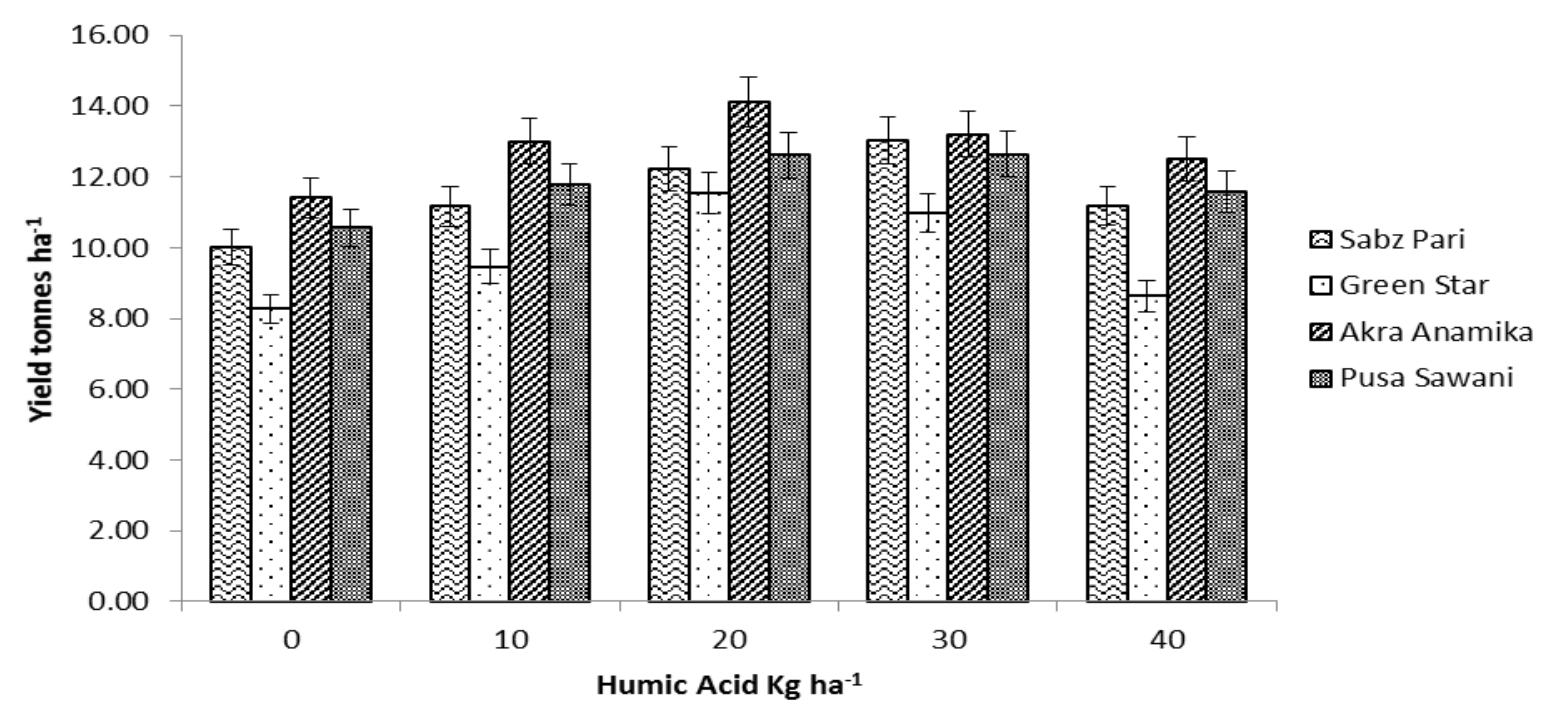

Figure 6. Fresh pod yield of different okra cultivars as affected by humic acid levels. Each bar represents the average yield of okra cultivars in response to different doses of humic acid. The error bar on each vertical bar shows standard error

\section{Conclusion}

Okra cultivar Arka Anamika performed outstanding in almost all growth and yield attributes among the under test cultivars while humic acid amendment @ $20 \mathrm{~kg} \mathrm{ha}^{-1}$ 
improved majority of the growth and yield characteristics of okra plant.

\section{Authors' contributions}

Conceived and designed the experiments: $\mathrm{N}$ Haider, M Alam, H Muhammad \& SU Haq, Performed the Experiments: N Haider, M Alam \& I Gul, Analyzed the Data: N Haider, A Rab, SU Haq \& S Hussain, Contributed reagents/ materials/ analysis tools: $\mathrm{N}$ Haider, S Hussain, I Gul \& A Rab, Wrote the paper: N Haider \& M Alam.

\section{References}

1. Kumar P, Rana DK, Singh V \& Shah KHN (2015). Effect of humic acid on growth, yield and quality of okra (Abelmoschus esculentus L.) cv. Arka Anamika under subtropical condition of Garhwal Himalaya. Int J I Res Sci Tech 9(8): 026-030.

2. Kirn A, Kashif SR \& Yaseen M (2010). Using indigenous humic acid from lignite to increase growth and yield of okra (Abelmoschus esculentus L.). Soil and Environ J 29(2): 187-197.

3. National Food Security and Research of Pakistan (NFS \& R). 2012-13. Fruit, vegetables and vondiments statistics of Pakistan. NFS \& R. 933(14).

4. Amjad M, Sultan M, Anjum MA, Ayyub CM \& Mushtaq M (2001). Comparative study on the performance of some exotic okra cultivars. Int J Agric and Biol 3(4): 423-425.

5. Dash GB \& Misra PK (1995). Variation and character association of fruit yield and its component characters in okra. Current Agric Res 8: 123-127.

6. Calvo P, Nelson L \& Kloepper JW (2014). Agricultural uses of plant bio stimulants. Plant and Soil 383(1): 3-41.

7. Pettit RE (2004). Organic matter, humus, humate, humic acid, fulvic acid and humin: Their importance in soil fertility and plant health. Available at http://fertiorganicos.com/english/images/l ib/organic_matter_humus_humate_humic _acid_fulvic_acid.pdf cti research. (Accessed 7 May 2015).

8. Mato MC, Fabregas R \& Mendez J (1971). Inhibitory effect of soil humic acids on indole acetic acid oxidase. Soil Biol Biochem 3: 285-288.

9. Schnitzer EA \& Wightman F (1974). Metabolism of auxin in higher plants. Ann Rev Plant Physiol 25: 487-513.

10. Brady NC \& Weil RR (2008). The nature and properties of soils. Europ $J$ Soil and Biol 42(1): 65-69.

11. Kulikova NA, Stepanova EV \& Koroleva OV (2005). Use of humic substances to remediate polluted environments: from Theory to practice. springer, Netherlands pp. 285310.

12. Steel RGD \& Torrie JA (1997). Principle and procedures of statistics, $2^{\text {nd }}$ ed. USA; McGraw Hill pp: 183-193.

13. Khan AK, Khan FA, Smiullah, Ijaz U, Ali A \& Nawaz S (2013). Genetics of yield and physiological attributes in okra under wastewater. Int J Agric and Crop Sci 6(11): 750-756.

14. Naheed Z, Ayaz A, Rehman A, Khan NA, Ahmad SQ, Hamid FS, Waheed A, Asghar S \& Khan MS (2013). Agronomic traits of okra cultivars under agro-climatic conditions of Baffa (KPK) Pak J Mater Environ Sci 4(5): 655-662.

15. Sadiq WM, Amin N \& Zoor S (1988). Performance of okra cultivars under soil and climatic conditions of Peshawar. Sarhad J Agric 4(5): 633-637.

16. Abolina BI \& Tashkhadzhaev AT (1968). Effects of coal-humic fertilizers on the activity of physiological processes in plants and in the yield of potatoes in Uzbekistan. Guminovye Udabr 1: 118-126.

17. Salman SR, Abou-hussain SD, AbdelMawgoud AMR \& El-Namr MA (2005). Fruit yield and quality of watermelon as 
affected by hybrids and humic acid application. J Ap Sc Res 1(1): 51-58.

18. Arancon NQ, Edwards CA, Lee $S$ \& Atiyeh R (2003). Effect of humic acids derived from cattle, food and paperwaste vermin compost on growth of green house plants. Pedobiologia 47: 741-744.

19. Partap PS, Dhankhar BS \& Pandita ML (1979). Inter-relationship and path analysis studies in okra (Abelmoschus esculentus L. Moench.). Haryana Agric Univ J Res 9: 317-321.

20. Falusai OA, Dangana MC, Daudu OY \& Desilva JAT (2007). Studies on morphological and yield parameters of three varieties of Nigerian okra (Abelmoschus esculentus L.) Monech J Hortand Forst 4(7): 126-128.

21. Madronova L, Kozler J, Cezikova J, Novak J \& Janos P (2000). Humic acid from coals of the north-bohemian coal field. Soil Sci and Plant Analysis 28: 787-796.

22. Paksoy M, Türkmen Ö \& Dursun A (2010). Effects of potassium and humic acid on emergence, growth and nutrient contents of okra (Abelmoschus esculentus L.) seedling under saline soil conditions. Africa J Biotech 9(33): 53435346.

23. Akinyele BO \& Osekita OS (2011). Genotype $\times$ environment interaction in NH47-4 variety of okra (Abelmoschus esculentus L.) Moench Int J Gen and Mole Bio 3(4): 55-59.

24. Rahman K, Waseem K, Kashif M, Jilani MS, Kiran M, Ghazanfarullah \& Mamoon-Ur-Rahshid M (2012). Performance of different okra (Abelmoschus esculentus L.) cultivars under the agro-climatic conditions of Dera Ismail Khan. Pak J Sci 64(4): 224228.

25. Nelson PV \& Niedziela CE (1998). Effect of calcium sources and temperature regimes on calcium deficiency during hydroponic forcing of tulip. Sci Hort 73: 137-150.

26. Gad N, Moez A \& Kandil H (2015). Response of Okra (Hibiscus esculentus) growth and productivity to cobalt and humic acid rates. Int $J$ Chem Tech Res 8(4): pp. 1782-1791.

27. Hussain S, Sajid M, Amin N, Alam S \& Iqbal Z (2006). Respons of okra (Abelmoschus esculentus L.) cultivars to different sowing times. J Agric and Bio Sci 01(1): 55-59.

28. Singh KB \& Singh HN (1977). Path coefficient analysis for yield in okra. Indian J Agric Sci 49: 244-246.

29. Albayrak S \& Camas N (2005). Effects of different levels and application times of humic acid on root and leaf yield and yield components of forage turnip (Brassica rapa L.). J Agro 42: 130-133.

30. Brownell JR, Nordstrom GMarihart J \& Jorgensen G (1987). Crop responses from two new leonardite extracts. Sci Total Environ 62: 491-499.

31. Karakurt Y, Unlu H, Unlu H \& Padem H (2009). The influence of foliar and soil fertilization of humic acid on yield and quality of pepper. Acta Agri Scandi Sec B Plant Soil Sci 59(3): 233-237.

32. Yildirim E (2007). Foliar and soil fertilization of humic acid affect productivity and quality of tomato. Acta Agric Scand Sec B -Soil and Plant Sci 57(2): 182-186. 